\title{
Potential pathogenic mechanisms involved in the association between lichen planus and hepatitis $\mathrm{C}$ virus infection (Review)
}

\author{
SIMONA ROXANA GEORGESCU ${ }^{1,2}$, MIRCEA TAMPA $^{1,2}$, MADALINA IRINA MITRAN $^{1,3}$, \\ CRISTINA IULIA MITRAN ${ }^{1,3}$, MARIA ISABELA SARBU ${ }^{2}$, ILINCA NICOLAE $^{1}$, CLARA MATEI $^{2}$, \\ CONSTANTIN CARUNTU ${ }^{4,5}$, MONICA NEAGU $^{6,7}$ and MIRCEA IOAN POPA ${ }^{3,8}$
}

${ }^{1}$ Department of Dermatology, 'Victor Babes' Clinical Hospital for Infectious Diseases, 030303 Bucharest; Departments of ${ }^{2}$ Dermatology and ${ }^{3}$ Microbiology, 'Carol Davila' University of Medicine and Pharmacy, 020021 Bucharest;

${ }^{4}$ Department of Dermatology, 'Prof. N. Paulescu' National Institute of Diabetes, Nutrition and Metabolic Diseases, 011233 Bucharest; ${ }^{5}$ Department of Physiology, 'Carol Davila' University of Medicine and Pharmacy, 050474 Bucharest;

${ }^{6}$ Department of Immunology, 'Victor Babes' National Institute of Pathology, 050096 Bucharest; ${ }^{7}$ Faculty of Biology University of Bucharest, 050095 Bucharest; ${ }^{8}$ 'Cantacuzino' National Medico-Military Institute for

Research and Development, 050096 Bucharest, Romania

Received July 3, 2018; Accepted August 14, 2018

DOI: $10.3892 / \mathrm{etm} .2018 .6987$

\begin{abstract}
Lichen planus (LP) is an immune-mediated inflammatory disease that particularly affects the skin and mucous membranes. Its etiology remains elusive, however some trigger factors, including viral or bacterial antigens, drugs and metals, have been postulated. There is a higher prevalence of hepatitis $\mathrm{C}$ virus (HCV) infection among patients with LP, with some geographical variations. $\mathrm{HCV}$ is an enveloped RNA virus that belongs to the Flaviviridae family and in most instances causes chronic liver infections. It has been hypothesized that HCV may contribute to LP development, but the link between the two disorders is not fully understood. It is still debatable whether HCV leads to the occurrence of LP lesions directly by replication inside the infected cells or indirectly by activating immunological pathways. Molecular studies have revealed HCV RNA in specimens collected from patients with LP. The autoimmune theory was also suggested given that several studies have revealed viral replication and immune response activation associated with autoantibody synthesis. The aim of this review is to summarize the main potential mechanisms involved in the association between LP and HCV infection. Understanding the link between the two disorders may shed some light on the pathogenesis of LP, which is a challenging issue.
\end{abstract}

Correspondence to: Dr Madalina Irina Mitran, Department of Dermatology, 'Victor Babes' Clinical Hospital for Infectious Diseases, 37 Dionisie Lupu Street, 030303 Bucharest, Romania E-mail: madalina.irina.mitran@gmail.com

Key words: lichen planus, hepatitis C, pathogenesis, viral replication, immune response

\section{Contents}

1. Introduction

2. HCV infection and cutaneous manifestations

3. Epidemiological data

4. Clinical and histopathological aspects

5. Mechanisms involved in the link between LP and HCV infection

6. HCV infection and oral cancer

7. Conclusion

\section{Introduction}

Globally, there are 120-130 million individuals infected with hepatitis $\mathrm{C}$ virus (HCV) and 3-4 million new cases are identified each year (1). The main risk factors for getting the infection are the use of injectable drugs, the contact with contaminated instruments and blood transfusions from unscreened subjects (2). HCV, first described in 1989, is a single stranded RNA virus, that belongs to the Flavoviridae family. HCV is a significant cause of liver cirrhosis and hepatocellular carcinoma $(3,4)$. To date, seven genotypes have been described and their prevalence present certain geographical variations. The pathogenesis of the infection involves the activation of cytotoxic $\mathrm{T}$ lymphocytes which during the fight against the virus lyse the infected hepatocytes and produce liver damage (5).

Mokni et al were the first to note the association between HCV and lichen planus (LP) in 1991. They reported a case of a patient who presented with an eruption consisting of violaceous papules disseminated on his arms and trunk. Laboratory findings showed elevated transaminases and further tests confirmed the diagnosis of HCV infection. A cutaneous biopsy established the diagnosis of LP (6). Three years later, the first cases of oral lichen planus (OLP) in association with HCV 
infection were notified. These studies were published shortly after the isolation of HCV in 1989 (7).

LP is a chronic T cell-mediated dermatosis of unknown etiology, which affects the skin, mucous membranes, hair and nails (8). One of the main histopathological features of LP is the vacuolar degeneration of the keratinocytes in the basal layer. This phenomenon is the result of the action of $\mathrm{T}$ helper lymphocytes, T cytotoxic lymphocytes, natural killer cells and dendritic cells that predominate in the inflammatory infiltrate. Thus, the main pathogenic mechanisms are increased apoptosis of keratinocytes and the inhibition of apoptosis of T lymphocytes (9-11). The trigger factors remain unknown. LP is associated with certain pathological conditions such as autoimmune diseases, malignancies, stress and viral infections, of which the most notable is HCV infection $(9,12)$.

In the following sections we present the main studies regarding the relationship between $\mathrm{LP}$ and $\mathrm{HCV}$.

\section{HCV infection and cutaneous manifestations}

Numerous studies have shown that a great number of patients with chronic hepatitis C (40-75\%) present extrahepatic manifestations (13). Cacoub et al conducted a study on 1,614 patients with chronic HCV infection and observed that $74 \%$ of them had at least one extrahepatic manifestation, arthralgia, paraesthesia and myalgia being the most common symptoms. Pruritus was identified in $15 \%$ of cases and LP in $1 \%$. They found that the main risk factors associated with extrahepatic manifestations are female gender, old age and severe hepatic fibrosis (14). Cutaneous manifestations are present in up to $17 \%$ of $\mathrm{HCV}$ positive patients. There is important evidence that HCV infection is associated with cryoglobulinemia, LP and porphyria cutanea tarda (15).

The mechanisms involved in the development of cutaneous manifestations in patients with HCV infection are controversial. Viral particles have been identified in various cells (keratinocytes, lymphocytes), a finding which raised the hypothesis that HCV exerts a direct cytopathic effect. Another theory advocates that the virus acts at the level of different organs, and skin manifestations are actually the result of the functional impairment of those organs (16). The theory of autoimmunity is also considered. This theory is supported by the detection of many circulating autoantibodies in HCV patients and the tropism of the virus for lymphocytes that promotes the proliferation of B cells (17).

\section{Epidemiological data}

The link between LP and HCV is supported by several epidemiological studies which investigated the prevalence of HCV infection among LP patients (18-24). The recent meta-analysis by Lodi et al revealed that on average $22.3 \%$ of LP patients had anti-HCV antibodies with significant variability depending on the geographic region, data being obtained from the analysis of 70 studies on 6,378 patients. The highest incidence of $\mathrm{HCV}$ infection among LP patients was recorded in Japan and Europe, the Mediterranean region (25). Similar results were revealed in the meta-analysis by Shengyuan et al (26).

The meta-analysis by Petti et al, which focused on the link between OLP and HCV, highlighted that the association globally occurs in $2 \%$ of OLP cases, suggesting that testing patients with OLP for HCV infection should only be performed in countries with an increased number of cases of HCV infection. They draw attention to the fact that the relationship between HCV infection and OLP is dependent on the prevalence of the infection in the analyzed population (27). This observation is also confirmed by the meta-analysis by Alaizari et al that revealed geographical differences, for example in France only 4\% of subjects with OLP had HCV infection, compared to Italy where the incidence was $\sim 30 \%$ and Japan $62 \%$. Alaizari pointed out a 6-fold higher risk of HCV infection among OLP patients (28).

Genetic factors may be responsible for the geographical differences (29). A study conducted in Italy, which investigated genetic aspects, revealed that HLA DR6 alleles are more common in patients with OLP and HCV infection, compared to those without HCV infection. It has been concluded that this finding could provide an explanation for the geographical variability of the association between LP and HCV and suggested that a molecular mimicry between regions of HLA DR6 allele and $\mathrm{HCV}$ components may be involved or the presentation of certain HCV encoded peptides by HLA DR6 to T lymphocytes might result in the development of lichenoid reactions (30).

If a specific genotype is involved, it is still a debatable topic. In their study, Lodi et al included 39 LP patients infected with $\mathrm{HCV}$; the genotyping was performed in 33 patients with detectable viremia. The prevalent genotype was $1 \mathrm{~b}$ in $51 \%$ of patients (17 cases), followed by $2 \mathrm{a}$ ( 9 cases), 1a ( 2 cases) and $2 \mathrm{~b}$ ( 1 case); in 4 cases the result was indeterminate (31). In the study by Imhof et al genotype 1b was also most commonly identified (83\% of the patients) (18). Femiano and Scully raised the hypothesis that the HCV genotype might influence the clinical aspect of LP (32).

Another approach of the link between LP and HCV infection is to investigate the prevalence of OLP in HCV infected patients, but such studies are fewer. Henderson et al analyzed the oral disorders among HCV patients (40 patients) and identified an increased prevalence of OLP (20\%), but the diagnosis of OLP was not confirmed by histopathological examination. Moreover, the study revealed that $\mathrm{HCV}$ patients suffer more frequently from oral conditions such as caries, gingivitis and dryness (33). In addition, Grossmann et al analyzed the prevalence of oral mucosal lesions and variations in normal aspect of oral mucosa in patients with chronic hepatitis $\mathrm{C}$ and found that over $90 \%$ of them had changes of the oral mucosa. The most common were Fordyce's spots (44.7\%), followed by lingual varicosities (31.2\%). However, OLP was the only associated disorder with statistical significance (34).

Conversely, there are studies which did not reveal an association between LP and HCV infection. The study by Stojanovic et al on $173 \mathrm{LP}$ patients from Slovenia revealed that only $1.2 \%$ of them had anti-HCV antibodies, with no link between the two diseases (35). Another study, conducted in China, also found no association between LP and HCV, anti$\mathrm{HCV}$ antibodies being detected in only $0.7 \%$ of patients (36). Other studies have also showed the lack of association between LP and hepatitis C (37-39).

Ali and Suresh conducted a study that included 40 patients with OLP. They identified a strong positive correlation between the level of transaminases and erosive OLP. The link between 
HCV infection and OLP could not be evaluated, anti-HCV antibodies being negative in all patients. In medical literature, the incidence of liver disease in patients with LP varies between $0.1-35 \%$ (40). In addition, Bombeccari et al observed a positive correlation between elevated levels of transaminases and LP exacerbation in HCV positive patients. They recommended the periodic evaluation of transaminases among LP patients with liver diseases, considering that the elevation of aspartate transaminase (AST) and alanine transaminase (ALT) may be an indicator of LP evolution (41).

\section{Clinical and histopathological aspects}

Several studies focused on the evaluation of clinical and histopathological differences between LP patients with and without HCV infection. It has been noted that OLP patients with $\mathrm{HCV}$ infection have more severe and extensive forms. In these patients the OLP evolution is chronic and the response to classical treatments is reduced, with a poor prognosis. It seems that there is a correlation between the severity of liver disease and the exacerbation of OLP lesions (15).

Gimenez Garcia and Pérez-Castrillón conducted a study on 101 patients with cutaneous and/or oral LP and obtained a statistically significant correlation between OLP and HCV infection only in the case of erosive OLP (42). In other studies, the erosive form was also the most frequently diagnosed $(15,43)$. In addition, erosive OLP appears to be more common in patients with LP and liver diseases (42). However, the study by Mignogna et al showed that the reticular type was more common in $\mathrm{HCV}$-positive compared to $\mathrm{HCV}$-negative patients ( $25 \mathrm{vs} .18 .7 \%$ ), and plaque lesions were more common in those without $\mathrm{HCV}$ infection. The erosive type was found in equal proportions in the two groups (44). Romero et al analyzed 7 patients with OLP and anti-HCV antibodies and 55 patients with OLP without anti-HCV antibodies. In the case of HCV positive patients, lesions on lips, tongue and gums were more frequently observed. In both groups the reticular type was the most common, but the number of lesions was higher in the HCV positive ones (45).

No histopathological differences of LP lesions were observed in $\mathrm{HCV}$ positive patients compared to $\mathrm{HCV}$ negative patients (46). Mega et al analyzed histological and immunohistochemical aspects of samples taken from OLP patients with HCV infection, patients with idiopathic OLP and patients with oral lichenoid reactions and observed similar histological features. However, a higher amount of CD8 lymphocytes was found in the lamina propria in patients with OLP and HCV infection and a lower amount in patients with oral lichenoid reactions compared to idiopathic OLP. Regarding CD4 lymphocytes, there were no differences between the three studied groups (47). Some authors did not detect differences in the proportion of $\mathrm{T}$ and $\mathrm{B}$ lymphocytes in the inflammatory infiltrate (48).

\section{Mechanisms involved in the link between LP and HCV infection}

Although in many studies the association between LP and HCV has been observed, the deep mechanisms involved have not been clearly elucidated. Several theories bring various factors to our attention that may contribute to the development of LP lesions.

Viral replication in keratinocytes. Although, hepatocytes represent the main site where $\mathrm{HCV}$ replicates, viral replication was also found in other tissues (49). Some investigators have identified viral RNA in the skin and oral mucosa, with a higher rate in oral tissue (49-52).

Lazaro et al included in their study patients with chronic hepatitis C without LP (group 1), patients with LP and chronic hepatitis $\mathrm{C}$ (group 2), and patients with LP without hepatitis $\mathrm{C}$ (group 3). Biopsies were taken from all patients. Viral RNA was detected in keratinocytes in $69 \%$ of group 1 patients, in all group 2 patients and was not identified in group 3 patients (53). Nagao et al also identified viral replication in OLP lesions, suggesting its role in pathology (54). The study by Arrieta et al, which included 23 patients with OLP, 14 of them having anti-HCV antibodies, and 5 patients with chronic hepatitis $\mathrm{C}$ without OLP, revealed viral replication in epithelial cells in all HCV positive patients, irrespective of the presence of OLP (a prior biopsy from the oral mucosa was performed) (55). Since HCV was also identified in the normal mucosa, it has been suggested that the virus has no direct effect on keratinocytes (50).

In contrast, the study by Harden et al on a small group of patients did not detect viral RNA in LP samples taken from patients with chronic hepatitis $\mathrm{C}$ and did not reveal any improvement of the skin lesions following HCV specific therapy (56). Femiano and Scully did not identify HCV RNA in the oral mucosa samples from patients with OLP and HCV infection, but they detected HCV RNA in peripheral blood lymphocytes (32).

Figueiredo et al suggested that the factor involved in the occurrence of OLP lesions is primarily related to the host peculiarities, the host immune response playing a more important role than viral factors (57).

The autoimmune theory. The theory that advocates the presence of an autoimmune process is supported by the identification of autoantibodies in the serum of patients with LP and HCV infection. In addition, in these patients, autoimmune diseases such as autoimmune thyroiditis, and CREST syndrome are often diagnosed (56).

Lodi et al revealed circulating antibodies against epithelial antigens in patients with HCV infection and LP but without showing their role in pathogenesis (58). The study by Łapinski et al, including patients with chronic HCV infection (25 of them were immunosuppressed), found autoantibodies in the serum of $32.5 \%$ immunocompetent and $16 \%$ immunosuppressed subjects. Antinuclear antibodies have been most commonly identified (59). However, Carrozzo et al revealed that patients with LP infected with HCV do not have higher titers of autoantibodies than those HCV negative. Higher levels of serum immunoglobulins were identified; this can be explained by the presence of cryoglobulins in these patients (60).

It is thought that HCV induces alterations of antigenic structures of oral mucosa resulting in the activation of cytotoxic $\mathrm{T}$ lymphocytes or the initiation of a humoral response followed by the production of antibodies directed against the modified structures of the host (61). Some authors suggested 
that long-term evolution of $\mathrm{HCV}$ infection might lead to an abnormal immune response (62). In addition, HCV infection is associated with a chronic inflammatory status that may contribute to this process (63).

The hypothesis of a possible molecular mimicry involved in the association between LP and HCV infection has been raised, but some authors rejected this theory $(24,46)$. The study by Lucchese revealed an immune cross-reactivity, which could be involved in LP pathogenesis. It seems that the immunogenic peptides SSSSSSS, QEQLEKA, LLLLLLA, and MLSGNAG are expressed by HCV, EBV, HHV-7, HSV-1 and CMV viruses but are also found in the structure of three human proteins, pinin, desmoglein-3, and plectin, which are part of the hemidesmosome and desmosome structure (64).

The role of oxidative stress. Petti et al suggested that oxidative stress could underlie the relationship between OLP and HCV (27). Breaking the balance between oxidants and antioxidants can result in the alteration of immune response with consequences on defence mechanisms against HCV $(27,65,66)$. In addition, it should be noted that there are numerous studies attesting the increased level of oxidative stress in patients with LP (67-70). Azizi and Farshchi analyzed the level of antioxidants in 48 patients with erosive OLP and revealed a significantly lower antioxidant capacity compared to healthy subjects (71). Aly and Shahin evaluated oxidative stress markers in patients with cutaneous LP, including 45 patients with LP and 45 healthy volunteers and detected an imbalance between oxidants and antioxidants. They identified increased levels of nitric oxide, malondialdehyde and superoxide dismutase; in contrast, the level of catalase was low (72).

On the other hand, studies have shown that HCV is involved in the disregulation of the oxidant-antioxidant balance (73). $\mathrm{HCV}$ core protein appears to be an important regulator of mitochondrial ROS (74). The study by Khadem Ansari et al showed that genotypes $1 \mathrm{a}$ and $1 \mathrm{~b}$ are most commonly associated with a higher level of oxidative stress, these genotypes being involved in more severe forms of disease (75).

The host immune response. Carrozzo et al postulated that the occurrence of OLP in HCV infected patients is related to the release of proinflammatory cytokines as a response to the presence of the virus (48). Recent research has emphasized that cytokines have an important role in the pathogenesis of OLP (10,76). In addition, polymorphism of some cytokine genes has been identified, and it has been suggested that this might underlie the genetic susceptibility of the disease (77). In line with this, Al-Mohaya et al reported that tumour necrosis factor (TNF)- $\alpha(-308 \mathrm{G} / \mathrm{A})$, TNF- $\beta(+252 \mathrm{~A} / \mathrm{G})$ and IL-10 (1082G/A, $-819 \mathrm{C} / \mathrm{T}$ and $-592 \mathrm{C} / \mathrm{A})$ polymorphisms might be involved in host susceptibility to develop OLP (78).

Considering that interferon (IFN) is involved in the pathogenesis of LP, Shaker et al detected the presence of myxovirus resistance protein $\mathrm{A}(\mathrm{Mx} \mathrm{A})$ in tissue samples collected from patients with LP; MxA protein is a protein produced under the action of interferon. They included in the study LP patients with and without $\mathrm{HCV}$ infection and a control group and observed higher MxA protein levels in LP patients compared to healthy subjects and higher levels in those with infection than those without infection. The conclusion was that HCV may be involved in the pathogenesis of LP, promoting the secretion of type 1 IFNs (79). The role of IFN in LP pathogenesis is also supported by the identification of several IFN-regulated genes in LP specimens (Mx1, IFI27, IFI30, G1P3) (80). Femiano and Scully found an increased level of TNF- $\alpha$ and low levels of IL1, IFN- $\gamma$ and IL8 in the serum of patients with HCV infection and erosive OLP compared to those with OLP without HCV infection (32).

HCV-specific T cells capable of secreting IFN- $\gamma$ were identified in oral mucosa of patients with OLP and HCV infection. In addition, CD4 and CD8 lymphocytes were more numerous in LP lesions than in peripheral blood. This demonstrates the presence of a local immune process most likely directed against epithelial cells presenting $\mathrm{HCV}$ antigens, a fact that might explain the role of the virus in LP pathogenesis (51). In contrast, patients with chronic hepatitis B virus (HBV) infection and OLP did not show HBV-specific T cells in oral mucosa samples $(49,51)$.

Regulatory $\mathrm{T}$ cells are important players in the host immune response (81). Farid et al analyzed regulatory $\mathrm{T}$ cells in 58 patients with chronic HCV infection, 30 of them associated immune-mediated cutaneous manifestations. The most frequent skin diseases were vasculitis of small vessels and LP. They noticed that those with cutaneous manifestations had fewer regulatory $\mathrm{T}$ cells in the peripheral blood than those without manifestations (82).

Since HCV infection occurs in those who use injectable drugs, they are often co-infected with HIV. These patients have a low CD4 cell count, which prevents the development of an in situ cytotoxic response; possibly explaning the small number of cases of OLP in HIV patients (83). Campisi et al analyzed 104 patients with chronic hepatitis C, HIV negative and $74 \mathrm{HIV} / \mathrm{HCV}$-co-infected patients and noted the absence of OLP in co-infected patients. However, the prevalence of OLP was also low in HCV infected patients (84).

The impact of interferon regimens. There are reported cases of worsening or de novo occurrence of LP lesions following therapy with interferon associated or not with ribavirin in $\mathrm{HCV}$ infected patients $(17,85)$. One of the mechanisms could be the effect of IFN- $\alpha$ on the cascade of cytokines involved in the pathogenesis of LP (85). Nagao et al described a case of exacerbation of OLP in a patient with HCV infection under treatment with interferon and ribavirin. Initially, the patient received IFN- $\beta$ for 2 weeks and after he continued with IFN- $\alpha-2 b$ in association with ribavirin. After 18 weeks, the treatment was interrupted given the exacerbation of OLP lesions. The lesions improved when the therapy was discontinued (86). Grossmann et al reported three cases of OLP worsening after chronic hepatitis $C$ therapy with interferon and ribavirin. They suggested that an autoimmune mechanism that was triggered by the simultaneous administration of the two drugs could be involved (87). In contrast, Doutre et al reported two cases of LP (one case of generalized LP and one of OLP) that improved following interferon therapy in two $\mathrm{HCV}$ infected patients (88).

However, the occurrence of LP after interferon therapy has also been found in patients without HCV infection. For example, Kütting et al described the case of a 74-year-old male treated with IFN- $\alpha$ for mycosis fungoides who developed oropharyngeal LP after 8 months of therapy. The lesions resolved when the therapy was discontinued (89). 
Considering that IFN is involved in the occurrence of LP, IFN-free regimens are recommended for patients with LP and HCV infection (15). The effect of interferon therapy on LP lesions still remains unclear $(90,91)$.

\section{HCV infection and oral cancer}

Carcinogenesis is a complex process and chronic inflammation seems to be a key factor in its development (92-96). Since OLP is a premalignant disorder, some authors paid attention to the role of $\mathrm{HCV}$ in its malignant transformation. According to the meta-analysis by Aghbari et al, $1.1 \%$ of OLP lesions progress into oral squamous cell carcinoma (OSCC) (97). It seems that HCV infection presents a 1.9-fold higher risk of oral cancer, and the association between OLP and HCV increases the risk by 3.2-fold (98). It seems that the risk of developing a squamous cell carcinoma occurs especially in $\mathrm{HCV}$ positive patients with long lasting OLP lesions (99). A British study that analyzed the incidence of chronic liver disease and HCV infection among patients with oral epithelial dysplasia did not reveal a positive correlation. Only two $(2.6 \%)$ of the 75 patients included in the study had anti-HCV antibodies. The authors concluded that there is insufficient evidence to support the role of HCV infection in the malignant transformation of OLP lesions and the reported cases are based on a serendipitous association (100). However, some authors have detected HCV replication in samples collected from oral cancer patients (54). Furthermore, the study by Lo Muzio et al which included 263 patients with OLP revealed that 14 of them developed OSCC. Among the patients who developed OSCC, 3 had anti-HCV antibodies (101). In this context a multidisciplinary approach is necessary (102).

\section{Conclusion}

There are numerous epidemiological studies that attest to the link between LP and HCV infection, with significant geographic variations suggesting the implication of genetic and environmental factors. Regarding the mechanisms which underlie this association, several theories have been postulated, but none of them clearly explain the pathogenic pathways involved. Most studies show that the lesions are the result of the host immune response to the viral components and not the result of the direct action of the virus.

\section{Acknowledgements}

Not applicable.

\section{Funding}

No funding was received.

\section{Availability of data and materials}

Not applicable.

\section{Authors' contributions}

All authors contributed to conceiving, writing and editing of the manuscript, and approved the final version.

\section{Ethics approval and consent to participate}

Not applicable.

\section{Consent for publication}

Not applicable.

\section{Competing interests}

The authors declare that they have no competing interests.

\section{References}

1. Morozov VA and Lagaye S: Hepatitis C virus: Morphogenesis, infection and therapy. World J Hepatol 10: 186-212, 2018.

2. Shepard CW, Finelli L and Alter MJ: Global epidemiology of hepatitis $C$ virus infection. Lancet Infect Dis 5: 558-567, 2005.

3. Ansaldi F, Orsi A, Sticchi L, Bruzzone B and Icardi G: Hepatitis $C$ virus in the new era: Perspectives in epidemiology, prevention, diagnostics and predictors of response to therapy. World J Gastroenterol 20: 9633-9652, 2014.

4. Ghasemi F, Rostami S and Meshkat Z: Progress in the development of vaccines for hepatitis $\mathrm{C}$ virus infection. World $\mathrm{J}$ Gastroenterol 21: 11984-12002, 2015.

5. Mukherjee R, Burns A, Rodden D, Chang F, Chaum M, Garcia N, Bollipalli N and Niemz A: Diagnosis and management of hepatitis C virus infection. J Lab Autom 20: 519-538, 2015.

6. Mokni M, Rybojad M, Puppin D Jr, Catala S, Venezia F, Djian R and Morel P: Lichen planus and hepatitis C virus. J Am Acad Dermatol 24: 792, 1991.

7. Gandolfo S, Carbone M, Carrozzo M and Gallo V: Oral lichen planus and hepatitis $\mathrm{C}$ virus (HCV) infection: Is there a relationship? A report of 10 cases. J Oral Pathol Med 23: 119-122, 1994.

8. Wagner G, Rose C and Sachse MM: Clinical variants of lichen planus. J Dtsch Dermatol Ges 11: 309-319, 2013.

9. Gorouhi F, Davari P and Fazel N: Cutaneous and mucosal lichen planus: A comprehensive review of clinical subtypes, risk factors, diagnosis, and prognosis. Sci World J 2014: 742826, 2014.

10. Mitran MI, Nicolae I, Ene CD, Mitran CI, Matei C, Ene C, Tampa M and Georgescu SR: Relationship between gamma-glutamyl transpeptidase activity and inflammatory response in lichen planus. Rev Chim 69: 739-743, 2018.

11. Le Cleach L and Chosidow O: Clinical practice. Lichen planus. N Engl J Med 366: 723-732, 2012.

12. Georgescu SR, Ene CD, Nicolae IL, Mitran M, Musetescu A, Matei C, Rusu LC and Tampa M: Reflectometric analysis for identification of various pathological conditions associated with lichen planus. Rev Chim 68: 1103-1108, 2017.

13. Akhter A and Said A: Cutaneous manifestations of viral hepatitis. Curr Infect Dis Rep 17: 452, 2015.

14. Cacoub P, Poynard T, Ghillani P, Charlotte F, Olivi M, Piette JC and Opolon P; MULTIVIRC Group: Extrahepatic manifestations of chronic hepatitis C. MULTIVIRC Group. Multidepartment virus C. Arthritis Rheum 42: 2204-2212, 1999.

15. Garcovich S, Garcovich M, Capizzi R, Gasbarrini A and Zocco MA: Cutaneous manifestations of hepatitis $\mathrm{C}$ in the era of new antiviral agents. World J Hepatol 7: 2740-2748, 2015.

16. Fachinelli LR, Silva EC, Figueiredo MG, Possa MS, Pelegrinelli FF and Molina RJ: Hepatitis C and cutaneous alterations. Rev Soc Bras Med Trop 45: 770-773, 2012.

17. Berk DR, Mallory SB, Keeffe EB and Ahmed A: Dermatologic disorders associated with chronic hepatitis C: Effect of interferon therapy. Clin Gastroenterol Hepatol 5: 142-151, 2007.

18. Imhof M, Popal H, Lee JH, Zeuzem S and Milbradt R: Prevalence of hepatitis $C$ virus antibodies and evaluation of hepatitis $C$ virus genotypes in patients with lichen planus. Dermatology 195: 1-5, 1997.

19. Sánchez-Pérez J, De Castro M, Buezo GF, Fernandez-Herrera J, Borque MJ and García-Díez A: Lichen planus and hepatitis C virus: Prevalence and clinical presentation of patients with lichen planus and hepatitis C virus infection. Br J Dermatol 134: 715-719, 1996.

20. Gerayli S, Meshkat Z, Pasdar A, Mosannen Mozafari P, Banihashemi E, Khajavi MA and Rasekhi J: The association between oral lichen planus and hepatitis $\mathrm{C}$ virus infection; a report from northeast of iran. Jundishapur J Microbiol 8: e16741, 2015. 
21. Konidena $A$ and Pavani BV: Hepatitis $C$ virus infection in patients with oral lichen planus. Niger J Clin Pract 14: 228-231, 2011.

22. de Mattos Camargo Grossmann S, de Aguiar MC, Teixeira R and do Carmo MA: Oral lichen planus and chronic hepatitis C: A controversial association. Am J Clin Pathol 127: 800-804, 2007.

23. Asaad T and Samdani AJ: Association of lichen planus with hepatitis C virus infection. Ann Saudi Med 25: 243-246, 2005.

24. Mahboob A, Haroon TS, Iqbal Z, Iqbal F and Butt AK: Frequency of anti-HCV antibodies in patients with lichen planus. J Coll Physicians Surg Pak 13: 248-251, 2003.

25. Lodi G, Pellicano R and Carrozzo M: Hepatitis $C$ virus infection and lichen planus: A systematic review with meta-analysis. Oral Dis 16: 601-612, 2010.

26. Shengyuan L, Songpo Y, Wen W, Wenjing T, Haitao Z and Binyou W: Hepatitis $C$ virus and lichen planus: A reciprocal association determined by a meta-analysis. Arch Dermatol 145: 1040-1047, 2009.

27. Petti S, Rabiei M, De Luca M and Scully C: The magnitude of the association between hepatitis $\mathrm{C}$ virus infection and oral lichen planus: Meta-analysis and case control study. Odontology 99: 168-178, 2011.

28. Alaizari NA, Al-Maweri SA, Al-Shamiri HM, Tarakji B and Shugaa-Addin B: Hepatitis C virus infections in oral lichen planus: A systematic review and meta-analysis. Aust Dent J 61: 282-287, 2016.

29. Farhi D and Dupin N: Pathophysiology, etiologic factors, and clinical management of oral lichen planus, part I: Facts and controversies. Clin Dermatol 28: 100-108, 2010.

30. Carrozzo M, Francia Di Celle P, Gandolfo S, Carbone M, Conrotto D, Fasano ME, Roggero S, Rendine S and Ghisetti V: Increased frequency of HLA-DR6 allele in Italian patients with hepatitis $\mathrm{C}$ virus-associated oral lichen planus. Br J Dermatol 144 803-808, 2001

31. Lodi G, Carrozzo M, Hallett R, D'Amico E, Piattelli A, Teo CG, Gandolfo S, Carbone M and Porter SR: HCV genotypes in Italian patients with HCV-related oral lichen planus. J Oral Pathol Med 26: 381-384, 1997.

32. Femiano F and Scully C: Functions of the cytokines in relation oral lichen planus-hepatitis C. Med Oral Patol Oral Cir Bucal 10 (Suppl 1): E40-E44, 2005.

33. Henderson L, Muir M, Mills PR, Spence E, Fox R, McCruden EA and Bagg J: Oral health of patients with hepatitis $\mathrm{C}$ virus infection: A pilot study. Oral Dis 7: 271-275, 2001

34. Grossmann SM, Teixeira R, de Aguiar MC, de Moura MD and do Carmo MA: Oral mucosal conditions in chronic hepatitis C Brazilian patients: A cross-sectional study. J Public Health Dent 69: 168-175, 2009

35. Stojanovič L, Lunder T, Poljak M, Marš T, Mlakar B and Matičič M: Lack of evidence for hepatitis $\mathrm{C}$ virus infection in association with lichen planus. Int J Dermatol 47: 1250-1256, 2008

36. Song J, Zhang Z, Ji X, Su S, Liu X, Xu S, Han Y, Mu D and Liu H: Lack of evidence of hepatitis in patients with oral lichen planus in China: A case control study. Med Oral Patol Oral Cir Bucal 21: e161-e168, 2016.

37. Remmerbach TW, Liese J, Krause S, Schiefke I, Schiefke F, Maier M and Liebert UG: No association of oral lichen planus and hepatitis $\mathrm{C}$ virus infection in central Germany. Clin Oral Investig 20: 193-197, 2016.

38. Zhou Y, Jiang L, Liu J, Zeng X and Chen QM: The prevalence of hepatitis $\mathrm{C}$ virus infection in oral lichen planus in an ethnic Chinese cohort of 232 patients. Int J Oral Sci 2: 90-97, 2010.

39. Tucker SC and Coulson IH: Lichen planus is not associated with hepatitis $\mathrm{C}$ virus infection in patients from north west England. Acta Derm Venereol 79: 378-379, 1999.

40. Ali AA and Suresh CS: Oral lichen planus in relation to transaminase levels and hepatitis C virus. J Oral Pathol Med 36: 604-608, 2007.

41. Bombeccari GP, Tettamanti M, Pallotti F, Spadari F and Giannì AB: Exacerbations of oral lichen planus and elevated levels of aminotransferases. Int J Dermatol 56: 842-849, 2017.

42. Gimenez-García R and Pérez-Castrillón JL: Lichen planus and hepatitis C virus infection. J Eur Acad Dermatol Venereol 17: 291-295, 2003.

43. Vanzela TN, Almeida IP, Bueno Filho R and Roselino AM: Mucosal erosive lichen planus is associated with hepatitis $C$ virus: Analysis of 104 patients with lichen planus in two decades. Int J Dermatol 56: e143-e144, 2017.

44. Mignogna MD, Lo Muzio L, Lo Russo L, Fedele S, Ruoppo E and Bucci E: Oral lichen planus: Different clinical features in HCV-positive and HCV-negative patients. Int J Dermatol 39: 134-139, 2000
45. Romero MA, Seoane J, Varela-Centelles P, Diz-Dios P and Otero XL: Clinical and pathological characteristics of oral lichen planus in hepatitis C-positive and -negative patients. Clin Otolaryngol Allied Sci 27: 22-26, 2002.

46. Lodi G, Scully C, Carrozzo M, Griffiths M, Sugerman PB and Thongprasom K: Current controversies in oral lichen planus: Report of an international consensus meeting. Part 1. Viral infections and etiopathogenesis. Oral Surg Oral Med Oral Pathol Oral Radiol Endod 100: 40-51, 2005.

47. Mega H, Jiang WW and Takagi M: Immunohistochemical study of oral lichen planus associated with hepatitis $\mathrm{C}$ virus infection, oral lichenoid contact sensitivity reaction and idiopathic oral lichen planus. Oral Dis 7: 296-305, 2001.

48. Carrozzo M, Dametto E, Fasano ME, Arduino P, Bertolusso G, Uboldi de Capei F, Rendine S and Amoroso A: Cytokine gene polymorphisms in hepatitis $\mathrm{C}$ virus-related oral lichen planus. Exp Dermatol 16: 730-736, 2007.

49. Baccaglini L, Thongprasom K, Carrozzo M and Bigby M: Urban legends series: Lichen planus. Oral Dis 19: 128-143, 2013.

50. Carrozzo M: Oral diseases associated with hepatitis C virus infection. Part 2: Lichen planus and other diseases. Oral Dis 14: 217-228, 2008

51. Pilli M, Penna A, Zerbini A, Vescovi P, Manfredi M, Negro F, Carrozzo M, Mori C, Giuberti T, Ferrari C, et al: Oral lichen planus pathogenesis: A role for the $\mathrm{HCV}$-specific cellular immune response. Hepatology 36: 1446-1452, 2002.

52. Kurokawa M, Hidaka T, Sasaki H, Nishikata I, Morishita K and Setoyama M: Analysis of hepatitis C virus (HCV) RNA in the lesions of lichen planus in patients with chronic hepatitis $\mathrm{C}$ : Detection of anti-genomic- as well as genomic-strand HCV RNAs in lichen planus lesions. J Dermatol Sci 32: 65-70, 2003.

53. Lazaro P, Olalquiaga J, Bartolomé J, Ortiz-Movilla N, Rodríguez-Iñigo E, Pardo M, Lecona M, Pico M, Longo I, García-Morrás P, et al: Detection of hepatitis C virus RNA and core protein in keratinocytes from patients with cutaneous lichen planus and chronic hepatitis C. J Invest Dermatol 119: 798-803, 2002.

54. Nagao Y, Sata M, Noguchi S, Seno'o T, Kinoshita M, Kameyama T and Ueno T: Detection of hepatitis $\mathrm{C}$ virus RNA in oral lichen planus and oral cancer tissues. J Oral Pathol Med 29: 259-266, 2000.

55. Arrieta JJ, Rodriguez-Iñigo E, Casqueiro M, Bartolomé J, Manzarbeitia F, Herrero M, Pardo M and Carreño V: Detection of hepatitis $\mathrm{C}$ virus replication by in situ hybridization in epithelial cells of anti-hepatitis $\mathrm{C}$ virus-positive patients with and without oral lichen planus. Hepatology 32: 97-103, 2000.

56. Harden D, Skelton H and Smith KJ: Lichen planus associated with hepatitis $C$ virus: No viral transcripts are found in the lichen planus, and effective therapy for hepatitis $C$ virus does not clear lichen planus. J Am Acad Dermatol 49: 847-852, 2003.

57. Figueiredo LC, Carrilho FJ, de Andrage HF and Migliari DA: Oral lichen planus and hepatitis $\mathrm{C}$ virus infection. Oral Dis 8: 42-46, 2002.

58. Lodi G, Olsen I, Piattelli A, D'Amico E, Artese L and Porter SR: Antibodies to epithelial components in oral lichen planus (OLP) associated with hepatitis C virus (HCV) infection. J Oral Pathol Med 26: 36-39, 1997.

59. Łapiński TW, Rogalska-Płońska M, Parfieniuk-Kowerda A, Swiderska M and Flisiak R: The occurrence of autoantibodies in patients with chronic $\mathrm{HCV}$ infection, including patients dialyzed and after kidney transplantation. Clin Exp Hepatol 2: 161-166, 2016.

60. Carrozzo M, Gandolfo S, Lodi G, Carbone M, Garzino-Demo P, Carbonero C, Porter SR and Scully C: Oral lichen planus in patients infected or noninfected with hepatitis $\mathrm{C}$ virus: The role of autoimmunity. J Oral Pathol Med 28: 16-19, 1999.

61. El Tawdy A and Rashed L: Downregulation of TLR-7 receptor in hepatic and non-hepatic patients with lichen planus. Int J Dermatol 51: 785-789, 2012

62. Al Robaee AA and Al Zolibani AA: Oral lichen planus and hepatitis C virus: Is there real association? Acta Dermatovenerol Alp Pannonica Adriat 15: 14-19, 2006.

63. Rosenthal E and Cacoub P: Extrahepatic manifestations in chronic hepatitis C virus carriers. Lupus 24: 469-482, 2015.

64. Lucchese A: A potential peptide pathway from viruses to oral lichen planus. J Med Virol 87: 1060-1065, 2015.

65. Georgescu S, Ene C, Tampa M, Matei C, Benea V and Nicolae I: Oxidative stress-related markers and alopecia areata. Mater Plast 53: 522-526, 2016.

66. Dinu LU, Ene CD, Nicolae IL, Tampa M, Matei CL and Georgescu SR: The serum levels of 8-hidroxy-deoxyguanosine under the chemicals influence. Rev Chim 65: 1319-1326, 2014. 
67. Sezer E, Ozugurlu F, Ozyurt H, Sahin S and Etikan I: Lipid peroxidation and antioxidant status in lichen planus. Clin Exp Dermatol 32: 430-434, 2007.

68. Panchal FH, Ray S, Munshi RP, Bhalerao SS and Nayak CS: Alterations in lipid metabolism and antioxidant status in lichen planus. Indian J Dermatol 60: 439-444, 2015.

69. Battino M, Greabu M, Totan A, Bullon P, Bucur A, Tovaru S, Mohora M, Didilescu A, Parlatescu I, Spinu T, et al: Oxidative stress markers in oral lichen planus. Biofactors 33: 301-310, 2008.

70. Mishra SS and Maheswari TU: Evaluation of oxidative stress in oral lichen planus using malonaldehyde: A systematic review. J Dermatol Dermatologic Surg 18: 2-7, 2014.

71. Azizi A and Farshchi F: Comparison of salivary and plasma antioxidant levels in lichen planus patients and healthy subjects. J Oral Pathol Med 41: 524-526, 2012.

72. Aly DG and Shahin RS: Oxidative stress in lichen planus. Acta Dermatovenerol Alp Pannonica Adriat 19: 3-11, 2010.

73. Choi J: Oxidative stress, endogenous antioxidants, alcohol, and hepatitis C: Pathogenic interactions and therapeutic considerations. Free Radic Biol Med 52: 1135-1150, 2012.

74. Medvedev R, Ploen D and Hildt E: HCV and oxidative stress: Implications for HCV life cycle and HCV-associated pathogenesis. Oxid Med Cell Longev 2016: 9012580, 2016.

75. Khadem Ansari MH, Omrani MD and Kheradmand F: Oxidative stress response in patients infected by diverse hepatitis $\mathrm{C}$ virus genotypes. Hepat Mon 15: e22069, 2015.

76. Tampa M, Caruntu C, Mitran M, Mitran C, Sarbu I, Rusu LC, Matei C, Constantin C, Neagu M and Georgescu SR: Markers of oral lichen planus malignant transformation. Dis Markers 2018: 1959506, 2018

77. Lu R, Zhang J, Sun W, Du G and Zhou G: Inflammation-related cytokines in oral lichen planus: An overview. J Oral Pathol Med 44: 1-14, 2015.

78. Al-Mohaya MA, Al-Harthi F, Arfin M and Al-Asmari A: TNF- $\alpha$ TNF- $\beta$ and IL-10 gene polymorphism and association with oral lichen planus risk in Saudi patients. J Appl Oral Sci 23: 295-301, 2015.

79. Shaker OG, Hantar N, El-Tahlawi S, El-Tawdi A, El-Hadidi H, Hantar S, El-Refai A and William R: Detection of myxovirus resistance protein $\mathrm{A}$ in lichen planus lesions and its relationship to hepatitis C virus. Br J Dermatol 160: 980-983, 2009.

80. Wenzel J and Tüting T: An IFN-associated cytotoxic cellular immune response against viral, self-, or tumor antigens is a common pathogenetic feature in 'interface dermatitis'. J Invest Dermatol 128: 2392-2402, 2008.

81. Bulman A, Neagu M and Constantin C: Immunomics in skin cancer-improvement in diagnosis, prognosis and therapy monitoring Curr Proteomics 10: 202-217, 2013.

82. Farid C, Sheikh WE, Swelem R and El-Ghitany E: Frequency of $\mathrm{FOXP}^{+}$regulatory $\mathrm{T}$ cells in the blood of chronic hepatitis $\mathrm{C}$ patients with immune mediated skin manifestations; Relationship to hepatic condition and viral load. Clin Lab 62: 2339-2348, 2016

83. Villarroel Dorrego M, Correnti M, Delgado R and Tapia FJ: Oral lichen planus: Immunohistology of mucosal lesions. J Oral Pathol Med 31: 410-414, 2002

84. Campisi G, Di Fede O, Craxì A, Di Stefano R and Margiotta V: Oral lichen planus, hepatitis $C$ virus, and HIV: No association in a cohort study from an area of high hepatitis $\mathrm{C}$ virus endemicity. J Am Acad Dermatol 51: 364-370, 2004.

85. Jadali Z: Dermatologic manifestations of hepatitis $C$ infection and the effect of interferon therapy: A literature review. Arch Iran Med 15: 43-48, 2012.

86. Nagao Y, Kawaguchi T, Ide T, Kumashiro R and Sata M: Exacerbation of oral erosive lichen planus by combination of interferon and ribavirin therapy for chronic hepatitis C. Int J Mol Med 15: 237-241, 2005.
87. Grossmann SM, Teixeira R, de Aguiar MC and do Carmo MA Exacerbation of oral lichen planus lesions during treatment of chronic hepatitis $\mathrm{C}$ with pegylated interferon and ribavirin. Eur J Gastroenterol Hepatol 20: 702-706, 2008

88. Doutre MS, Beylot C, Couzigou P, Long P, Royer P and Beylot J Lichen planus and virus $C$ hepatitis: Disappearance of the lichen under interferon alfa therapy. Dermatology 184: 229-233, 1992.

89. Kütting B, Böhm M,Luger TA and Bonsmann G: Oropharyngeal lichen planus associated with interferon- $\alpha$ treatment for mycosis fungoides: A rare side-effect in the therapy of cutaneous lymphomas. Br J Dermatol 137: 836-837, 1997.

90. Sayiner M, Golabi P, Farhat F and Younossi ZM: Dermatologic manifestations of chronic hepatitis $\mathrm{C}$ infection. Clin Liver Dis 21: 555-564, 2017.

91. Nagao $\mathrm{Y}$ and Sata M: Hepatitis $\mathrm{C}$ virus and lichen planus. J Gastroenterol Hepatol 19: 1101-1113, 2004.

92. Neagu M: The immune system - a hidden treasure for biomarker discovery in cutaneous melanoma. Adv Clin Chem 58: 89-140, 2012.

93. Neagu M, Caruntu C, Constantin C, Boda D, Zurac S, Spandidos DA and Tsatsakis AM: Chemically induced skin carcinogenesis: Updates in experimental models (Review). Oncol Rep 35: 2516-2528, 2016.

94. Brănişteanu DE, Brănişteanu DC, Stoleriu G, Ferariu D, Voicu CM, Stoica LE, Căruntu C, Boda D, Filip-Ciubotaru FM, Dimitriu A, et al: Histopathological and clinical traps in lichen sclerosus: A case report. Rom J Morphol Embryol 57 (Suppl): 817-823, 2016.

95. Georgescu SR, Sârbu MI, Matei C, Ilie MA, Caruntu C, Constantin C, Neagu M and Tampa M: Capsaicin: Friend or Foe in skin cancer and other related malignancies? Nutrients 9: 1365,2017

96. Tampa M, Matei C, Caruntu C, Poteca T, Mihaila D, Paunescu C Pitigoi G, Georgescu SR, Constantin C and Neagu M: Cellular impedance measurement - novel method for in vitro investigation of drug efficacy. Farmacia 64: 430-434, 2016.

97. Aghbari SMH, Abushouk AI, Attia A, Elmaraezy A, Menshawy A, Ahmed MS, Elsaadany BA and Ahmed EM: Malignant transformation of oral lichen planus and oral lichenoid lesions: A meta-analysis of 20095 patient data. Oral Oncol 68: 92-102, 2017

98. Manomaivat T, Pongsiriwet S, Kuansuwan C, Thosaporn W, Tachasuttirut $\mathrm{K}$ and Iamaroon $\mathrm{A}$ : Association between hepatitis $\mathrm{C}$ infection in Thai patients with oral lichen planus: $\mathrm{A}$ case-control study. J Investig Clin Dent 9: e12316, 2018.

99. Porter SR, Lodi G, Chandler K and Kumar N: Development of squamous cell carcinoma in hepatitis $\mathrm{C}$ virus-associated lichen planus. Oral Oncol 33: 58-59, 1997.

100. Jaber MA, Porter SR, Bain L and Scully C: Lack of association between hepatitis $\mathrm{C}$ virus and oral epithelial dysplasia in British patients. Int J Oral Maxillofac Surg 32: 181-183, 2003.

101. Lo Muzio L, Mignogna MD, Favia G, Procaccini M, Testa NF and Bucci E: The possible association between oral lichen planus and oral squamous cell carcinoma: A clinical evaluation on 14 cases and a review of the literature. Oral Oncol 34 239-246, 1998.

102. Raţiu MP, Purcărea IR, Popa F, Purcărea VL, Purcărea TV, Lupuleasa D and Boda D: Escaping the economic turn down through performing employees, creative leaders and growth driver capabilities in the Romanian pharmaceutical industry. Farmacia 59: 119-130, 2011. 